Review

\title{
Use of Incineration MSW Ash: A Review
}

\author{
Charles H. K. Lam, Alvin W. M. Ip, John Patrick Barford and Gordon McKay * \\ Department of Chemical Engineering, Hong Kong University of Science and Technology, Clear Water \\ Bay, Kowloon, Hong Kong; E-Mails: keking@ust.hk (C.H.K.L.); keiwm@ust.hk (A.W.M.I.); \\ barford@ust.hk (J.P.B.)
}

* Author to whom correspondence should be addressed; E-Mail: kemckayg@ust.hk;

Tel.: +85-223-588-412; Fax: +85-223-580-054.

Received: 15 May 2010; in revised form: 1 June 2010 / Accepted: 28 June 2010 /

Published: 2 July 2010

\begin{abstract}
This study reviews the characteristics of municipal solid waste incineration (MSWI) ashes, with a main focus on the chemical properties of the ashes. Furthermore, the possible treatment methods for the utilization of ash, namely, separation processes, solidification/stabilization and thermal processes, are also discussed. Seven types of MSWI ash utilization are reviewed, namely, cement and concrete production, road pavement, glasses and ceramics, agriculture, stabilizing agent, adsorbents and zeolite production. The practical use of MSWI ash shows a great contribution to waste minimization as well as resources conservation.
\end{abstract}

Keywords: municipal solid waste; fly ash; incineration; waste management; waste utilization; hazardous waste

\section{Introduction}

Thousands of millions of tons of municipal solid waste (MSW) are produced every year. Waste management and utilization strategies are major concern in many countries. Incineration is a common technique for treating waste, as it can reduce waste mass by $70 \%$ and volume by up to $90 \%$, as well as providing recovery of energy from waste to generate electricity. Generally, municipal solid waste incineration (MSWI) produces two main types of ash, which can be grouped as bottom ashes (BA) and fly ashes (FA). In this review, the utilization methods of MSWI ashes will be studied. 


\section{Waste Management in Different Countries}

The waste generated from MSWI usually ends up in two ways, disposed as landfill or for reuse as secondary raw materials. In most developed countries where land is scarce and environmental controls are tight, environmental policies tend to reduce landfill disposals as much as possible [1-3]. In Japan, about $80 \%$ of MSW is incinerated and the recycling and reuse of MSWI ash in different ways have been described [4-7]. In China, more than $80 \%$ of the MSW ends up as landfill, and compost production ranks as the second major application; only few processes involving the recycling of ashes have been undertaken [8]. The best management strategy for waste ashes is recycling and reusing. Different kinds of utilization methods are used in developed countries. Although the ashes contain high concentrations of heavy metals, salts, chloride and organic pollutants, which may limit the applications of reuse, the treatment of ashes will improve the environmental characteristics and enhance the possibility for reuse [9-13].

\section{MSW Incineration Processes}

The incineration process is separated into three main parts: incineration, energy recovery and air pollution control [14,15]. Figure 1 shows a schematic diagram depicting the common MSW incineration process.

Figure 1. Schematic Diagram of the MSW incineration process (Reproduced with permission from [16], published by Environmental Protection Department, the Government of the Hong Kong Special Administrative Region, 2009).

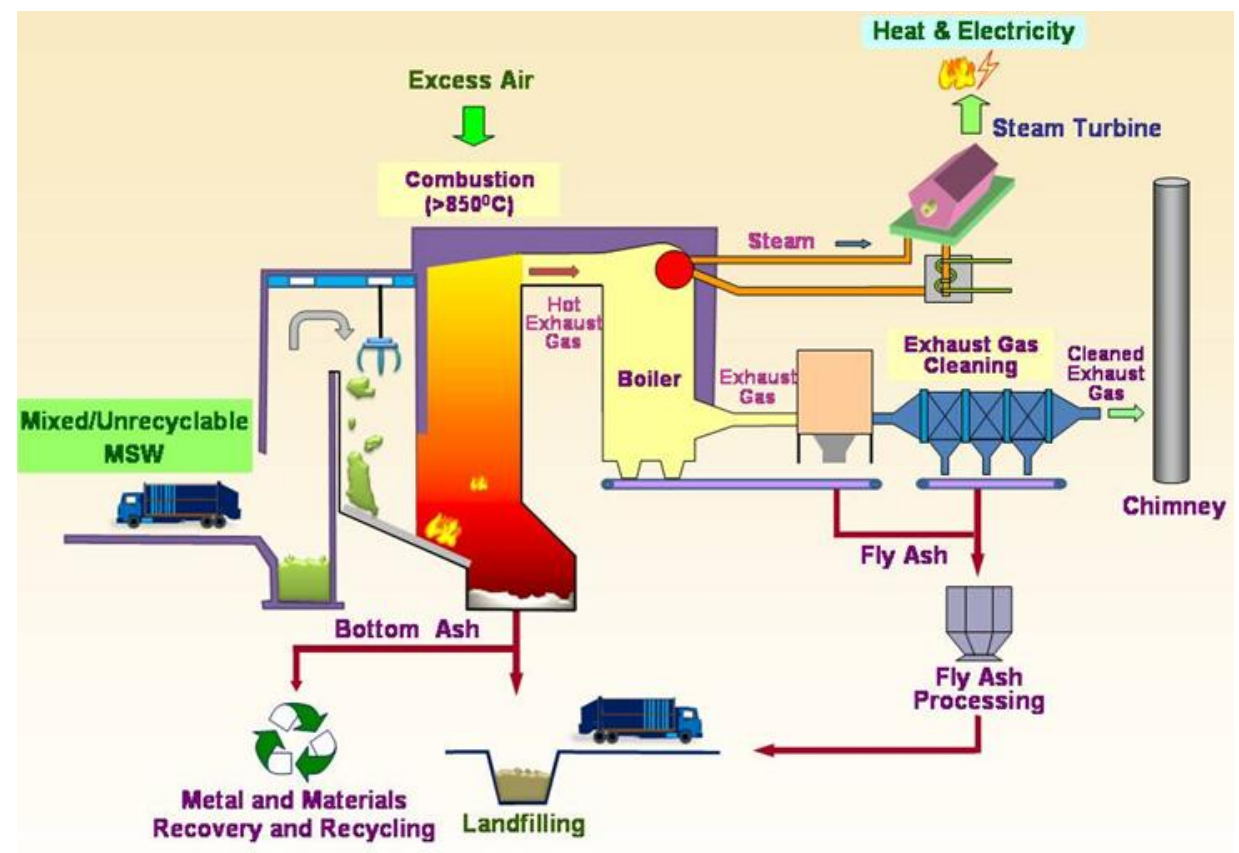

The MSW is fed into the furnace continually for incineration. Based on the Best Practical Means for the combustion of wastes, the combustion is enhanced by following the three T's guideline-high Temperature increases burnout, increased Turbulence exposes more waste surface and increases burnout, and a longer residence Time for the flue gas ( $>2$ seconds) and the MSW increases 
burnout - the temperature for incineration should be at least $850{ }^{\circ} \mathrm{C}$ with a residence time of more than two seconds. During the process, the air supply must be sufficient to ensure complete combustion of waste and to prevent the formation of dioxins and carbon monoxide.

For energy recovery, the heat generated from waste is used to produce steam in the boiler. Then the steam drives the turbine to generate electricity. The excess heat generated can also be used for other purposes, e.g., heating for swimming pools.

Air pollution is a major problem for incineration. In modern incinerators, an advanced pollution control system is designed to minimize the pollution and ensure compliance with environmental standards. A dry/wet scrubber is used to spray fine atomized slurry or lime powder into the hot exhaust gas in order to neutralize the acidic gases such as sulfur oxides and hydrogen chloride. An activated carbon column or injected activated carbon spray is used to adsorb the heavy metals and organic pollutants such as PCB and VOC in the exhaust gas [17]. A selective non-catalytic reduction system is used to remove nitrogen oxides by adding urea or ammonia for reaction to nitrogen, carbon dioxide and water. The bag filter system acts to filter and remove the fine particulates and dust particles [16].

\section{Ash Characterization Methods}

The properties of ashes can be separated into two parts: physical properties and chemical properties. By knowing the properties of ashes, mainly chemical properties, we can ensure selection of the most suitable way for ash utilization $[18,19]$.

Physical properties

- Particle size distribution

- Moisture content

- Bulk density

- Compressive strength

- Permeability

- Porosity

Chemical properties

- Chemical composition

- Loss on ignition

- Heavy metals and leachability

- Organic constituents

- Chloride content

\section{Characterization of Incineration Ashes}

The composition of municipal solid waste varies over time and from country to country, due to the differences in lifestyle and waste recycling processes of a country; the ash content will vary too. Generally, the chemical and physical characterization of ash will depend on the compositions of the raw MSW, the operational conditions, the type of incinerator and air pollution control system design [20]. The chemical composition shows that the major elements are $\mathrm{Si}, \mathrm{Al}, \mathrm{Fe}, \mathrm{Mg}, \mathrm{Ca}, \mathrm{K}, \mathrm{Na}$ and $\mathrm{Cl}$. Further, $\mathrm{SiO}_{2}, \mathrm{Al}_{2} \mathrm{O}_{3}, \mathrm{CaO}, \mathrm{Fe}_{2} \mathrm{O}_{3}, \mathrm{Na}_{2} \mathrm{O}, \mathrm{K}_{2} \mathrm{O}$ are the common oxides found in ash (Tables 1 and 2). 
$\mathrm{CaO}$ is the most abundant compound that exists in MSWI fly ash, which constitutes up to $46 \%$, but $\mathrm{SiO}_{2}$ is the most abundant compound that exists in MSWI bottom ash, containing up to $49 \%$.

Table 1. Oxide compositions in MSWI fly ash (FA) (wt\%).

\begin{tabular}{|c|c|c|c|c|c|c|c|c|}
\hline Authors & [21] & [22] & {$[23]$} & {$[24]$} & [25] & [26] & [27] & [28] \\
\hline Type & FA & FA & FA & FA & FA & FA & FA & FA \\
\hline $\mathrm{SiO}_{2}$ & 18.8 & 11.47 & 19.4 & 13.6 & 18.5 & 20.5 & 6.35 & 27.52 \\
\hline $\mathrm{Al}_{2} \mathrm{O}_{3}$ & 12.7 & 5.75 & 10.1 & 0.92 & 7.37 & 5.8 & 3.5 & 11 \\
\hline $\mathrm{CaO}$ & 24.3 & 29.34 & 19.7 & 45.42 & 37.5 & 35.8 & 43.05 & 16.6 \\
\hline $\mathrm{Fe}_{2} \mathrm{O}_{3}$ & 1.6 & 1.29 & 1.8 & 3.83 & 2.26 & 3.2 & 0.63 & 5.04 \\
\hline $\mathrm{MgO}$ & 2.6 & 3.02 & 2.8 & 3.16 & 2.74 & 2.1 & 1.38 & 3.14 \\
\hline $\mathrm{K}_{2} \mathrm{O}$ & 4.3 & 7.02 & 8.1 & 3.85 & 2.03 & 4 & 4.59 & \multirow{2}{*}{8.24} \\
\hline $\mathrm{Na}_{2} \mathrm{O}$ & 5.8 & 8.7 & 8.9 & 4.16 & 2.93 & 3.7 & 5.8 & \\
\hline $\mathrm{SO}_{3}$ & 6.4 & N/A & N/A & 5.18 & 14.4 & N/A & 4.64 & 8.34 \\
\hline $\mathrm{P}_{2} \mathrm{O}_{5}$ & 2.7 & 1.69 & N/A & N/A & 1.56 & N/A & N/A & N/A \\
\hline $\mathrm{TiO}_{2}$ & 1.5 & 0.85 & 1.9 & 3.12 & 1.56 & N/A & N/A & 1.88 \\
\hline
\end{tabular}

Table 2. Oxide compositions MSWI bottom ash (wt\%).

\begin{tabular}{|c|c|c|c|c|c|c|c|}
\hline $\begin{array}{l}\text { Authors } \\
\text { Tyne }\end{array}$ & $\begin{array}{c}{[29]} \\
\text { BA }(150-200 \mathrm{mesh})\end{array}$ & $\begin{array}{c}\text { [30] } \\
\text { MSWI ash }\end{array}$ & $\begin{array}{c}\text { [31] } \\
\text { MSWI ash }\end{array}$ & $\begin{array}{c}{[32]} \\
\text { MSWI ash }\end{array}$ & $\begin{array}{l}{[24]} \\
B A\end{array}$ & $\begin{array}{l}{[25]} \\
B A\end{array}$ & [27] \\
\hline $\mathrm{SiO}_{2}$ & 27.8 & 29.4 & 12.01 & 5.44 & 13.44 & 46.7 & 49.38 \\
\hline $\mathrm{Al}_{2} \mathrm{O}_{3}$ & 9.9 & 18 & 8.1 & 3.1 & 1.26 & 6.86 & 6.58 \\
\hline $\mathrm{CaO}$ & 25.9 & 27.2 & 13.86 & 42.55 & 50.39 & 26.3 & 14.68 \\
\hline $\mathrm{Fe}_{2} \mathrm{O}_{3}$ & 4 & 13.3 & 1.21 & 1.69 & 8.84 & 4.69 & 8.38 \\
\hline $\mathrm{MgO}$ & 3.3 & 1.6 & 2.62 & 1.83 & 2.26 & 2.22 & 2.32 \\
\hline $\mathrm{K}_{2} \mathrm{O}$ & 1.8 & 0.9 & 7.41 & 4.31 & 1.78 & 0.888 & 1.41 \\
\hline $\mathrm{Na}_{2} \mathrm{O}$ & 3.3 & 3.6 & 17.19 & 4.82 & 12.66 & 4.62 & 7.78 \\
\hline $\mathrm{SO}_{3}$ & N/A & N/A & N/A & 12.73 & 0.5 & 2.18 & 0.57 \\
\hline $\mathrm{P}_{2} \mathrm{O}_{5}$ & 6.9 & N/A & N/A & 1.62 & N/A & 0.855 & N/A \\
\hline $\mathrm{TiO}_{2}$ & 2 & N/A & N/A & 0.92 & 2.36 & 0.77 & N/A \\
\hline
\end{tabular}

For heavy metals, $\mathrm{Cr}, \mathrm{Cu}, \mathrm{Hg}, \mathrm{Ni}, \mathrm{Cd}, \mathrm{Zn}$ and $\mathrm{Pb}$ are the most commonly found in MSWI ash, and $\mathrm{Zn}$ and $\mathrm{Pb}$ usually exist in the largest amounts (fly ash and bottom ash shown in Tables 3 and 4, respectively). These metals may cause leaching problems and are harmful to the environment without proper treatment. Generally, the heavy metals content in fly ash is higher than in bottom ash due to the vaporization of metals during combustion and the process of metals adsorption on the surface of fly ash particles.

MSWI fly ash contains a much higher chloride content than MSWI bottom ash (Table 5 and 6, respectively). This may be due to the lime scrubber in the air pollution control system, which removes acidic gases such as $\mathrm{HCl}$, thus resulting in a high amount of chloride content remaining in fly ash after the air pollution control system. The loss on ignition of ashes is around 4-13\% for fly ash and 3-5\% for bottom ash (Table 7). 
Table 3. Heavy metals found in MSWI fly ash (FA) (mg/kg).

\begin{tabular}{cccccc}
\hline Authors & {$[10]$} & {$[33]$} & {$[34]$} & {$[35]$} & {$[36]$} \\
Type & FA & FA & FA & FA & FA \\
\hline $\mathrm{Ag}$ & $31-95$ & ND-700 & N/A & N/A & N/A \\
$\mathrm{As}$ & $31-95$ & $15-751$ & N/A & 93 & N/A \\
$\mathrm{Ba}$ & $920-1,800$ & $88-9,001$ & N/A & 4,300 & 539 \\
$\mathrm{Cd}$ & $250-450$ & $5-2211$ & 25.5 & 470 & 95 \\
$\mathrm{Co}$ & $29-69$ & $2.3-1,671$ & N/A & N/A & 14 \\
$\mathrm{Cr}$ & $140-530$ & $21-1,901$ & 118 & 863 & 72 \\
$\mathrm{Cu}$ & $860-1,400$ & $187-2,381$ & 313 & 1,300 & 570 \\
$\mathrm{Hg}$ & $0.8-7$ & $0.9-73$ & 52 & N/A & N/A \\
$\mathrm{Mn}$ & $0.8-1.7$ & $171-8,500$ & N/A & 1,600 & 309 \\
$\mathrm{Ni}$ & $95-240$ & $10-1,970$ & 60.8 & 124 & 22 \\
$\mathrm{~Pb}$ & $7,400-19,000$ & $200-2,600$ & 1496 & 10,900 & 2,000 \\
$\mathrm{Se}$ & $6.1-31$ & $0.48-16$ & N/A & 41 & N/A \\
$\mathrm{Zn}$ & $19,000-41,000$ & $2,800-152,000$ & 4,386 & 25,800 & 6,288 \\
$\mathrm{Sn}$ & $1,400-1,900$ & N/A & N/A & N/A & N/A \\
$\mathrm{Sr}$ & $80-250$ & N/A & N/A & 433 & 151 \\
$\mathrm{~V}$ & $32-150$ & N/A & N/A & 37 & N/A \\
\hline
\end{tabular}

Table 4. Heavy metals found in MSWI bottom ash (BA) (mg/kg).

\begin{tabular}{cccccc}
\hline $\begin{array}{c}\text { Authors } \\
\text { Type }\end{array}$ & {$[37]$} & {$[33]$} & {$[38]$} & {$[31]$} & {$[39]$} \\
\hline $\mathrm{Ag}$ & $4.1-14$ & $2-38$ & $8.5-10.7$ & N/A & N/A \\
$\mathrm{As}$ & $19-80$ & $1.3-45$ & $209-227$ & 160 & 13 \\
$\mathrm{Ba}$ & $900-2,700$ & $47-2,000$ & $1,104-1,166$ & N/A & N/A \\
$\mathrm{Cd}$ & $1.4-40$ & $0.3-61$ & $6.8-7.8$ & 110 & 3 \\
$\mathrm{Co}$ & $<10-40$ & $22-706$ & $49.6-53.1$ & N/A & N/A \\
$\mathrm{Cr}$ & $230-600$ & $13-1,400$ & $323-439$ & 260 & 900 \\
$\mathrm{Cu}$ & $900-4,800$ & $80-10,700$ & $4,139-4,474$ & N/A & 500 \\
$\mathrm{Hg}$ & $<0.01-3$ & $0.003-2$ & N/A & N/A & 2.6 \\
$\mathrm{Mn}$ & $<0.7-1.7$ & $50-3,100$ & $869-894$ & N/A & 280 \\
$\mathrm{Ni}$ & $60-190$ & $9-430$ & $216-242$ & N/A & 180 \\
$\mathrm{~Pb}$ & $1,300-5,400$ & $98-6,500$ & $2,474-2,807$ & N/A & 2,700 \\
$\mathrm{Se}$ & $0.6-8$ & ND-3.4 & $230-265$ & 130 & N/A \\
$\mathrm{Zn}$ & $1,800-6,200$ & $200-12,400$ & $4,261-4,535$ & N/A & 600 \\
$\mathrm{Sn}$ & $<100-1,300$ & N/A & N/A & 840 & 960 \\
$\mathrm{Sr}$ & $170-350$ & N/A & N/A & N/A & N/A \\
$\mathrm{V}$ & $36-90$ & N/A & N/A & N/A & N/A \\
\hline
\end{tabular}

Table 5. Chloride Content of MSWI fly ash (FA) (mg/kg).

\begin{tabular}{ccccccccccc}
\hline Authors & {$[24]$} & {$[25]$} & {$[37]$} & {$[40]$} & {$[32]$} & {$[41]$} & {$[27]$} & {$[28]$} & {$[36]$} & {$[42]$} \\
Type & FA & FA & FA & FA & FA & FA & FA & FA & FA & FA \\
\hline & 5,749 & 8,670 & $45,000-100,000$ & $19,000-210,000$ & $120,000-200,000$ & 131,000 & 83,800 & 103,200 & 157,200 & 215,000 \\
\hline
\end{tabular}


Table 6. Chloride Content of MSWI bottom ash (BA) (mg/kg).

\begin{tabular}{cccccc}
\hline $\begin{array}{c}\text { Authors } \\
\text { Type }\end{array}$ & {$[24]$} & {$[31]$} & {$[32]$} & {$[39]$} & {$[25]$} \\
& BA & BA & BA & BA & BA \\
\hline & 2,876 & 149,500 & 201,100 & 2,300 & 1,760 \\
\hline
\end{tabular}

Table 7. Loss on Ignition of MSWI fly ash (FA) and bottom ash (BA) (wt\%).

\begin{tabular}{cccccc}
\hline $\begin{array}{c}\text { Author } \\
\text { Type }\end{array}$ & {$[10]$} & {$[24]$} & {$[28]$} & {$[24]$} & {$[31]$} \\
& FA & FA & FA & BA & BA \\
\hline & 4.3 & 9.73 & 13.36 & 3.24 & 4.59 \\
\hline
\end{tabular}

Generally, the dioxin levels in fly ash in most countries has demonstrated values higher than $1 \mathrm{ng}$ I-TEQ/g (Table 8), which is the Japan Ministry of the Environment (2001) Environmental Quality Standard for Soils. The international emission standard limit for dioxin concentration in flue gas is $0.1 \mathrm{ng} \mathrm{I}-\mathrm{TEQ} / \mathrm{m}^{3}$. In order to minimize the flue gas dioxin concentration; the dioxin is removed from vapor phase to solid phase by lime scrubbing and activated carbon injection to adsorb dioxin [43-45]. Thus, the remaining air pollution control fly ash contains relatively high amounts of dioxin and is classified as hazardous waste [46-48]. There are a number of ways of minimizing dioxin/furan formation during MSW incineration which can significantly reduce the dioxin/furan. A two-stage approach system was designed to achieve complete combustion and minimize formation by a well controlled combustion system; and a well designed end-of-pipe treatment system to remove dioxins. In the combustion system, the combustion temperature should be above $1,000{ }^{\circ} \mathrm{C}$, the combustion residence time should be greater than $1 \mathrm{~s}$ and the combustion chamber turbulence should be represented by a Reynolds number greater than 50,000, with good MSW feed preparation and controlled feed rate. In the end-of-pipe treatment systems, very rapid gas cooling from 400 to $250{ }^{\circ} \mathrm{C}$ should be achieved. Semi-dry lime scrubbing and bag filtration coupled with activated carbon injection adsorption as end-of-pipe treatments can all play a role in prevention or minimization of dioxins in the final flue gas emission to the atmosphere [46].

Table 8. Dioxin in MSWI fly ash (FA) and bottom ash (BA) (ng I-TEQ/g).

\begin{tabular}{|c|c|c|c|c|c|c|c|}
\hline & Country & & China & & Korea & Japan & Taiwan \\
\hline & Authors & [49] & [20] & [44] & [50] & [51] & {$[52,53]$} \\
\hline & Type & FA & FA & FA & FA & FA & FA \\
\hline PCDD/F & & 7.53 & $0.98-1.5$ & 0.798 & $0.13-21$ & 6.7 & $0.47-2.3$ \\
\hline
\end{tabular}

\section{Process Treatment Methods}

In order to utilize the waste and reduce the environmental impact, three treatment methods have been introduced and may be classified as follows [11,54]:

- Separation processes

- Solidification/Stabilization

- Thermal methods 
In practice, it is common to start the treatment of ashes with the separation techniques, followed by thermal treatments or stabilization/solidification [55]. Based on different objectives of treating the ashes, strategies may vary. Reducing the environmental impact involves processes such as lowering the total concentration of the contaminants through washing, reducing the leachablity of contaminants by stabilization or decreasing the rate of contaminants leaching by solidification $[11,54,56,57]$.

\subsection{Separation Processes}

The objective of separation methods is to improve the quality of waste ashes and to enhance their utilization. The techniques include washing, leaching, electrochemical process and thermal treatment.

\subsubsection{Washing process}

This process is aimed at reducing the chloride, salts, alkali and heavy metal content by using a liquid solution as leachant (e.g., water, acid). The contaminants may be found in both bottom ash and fly ash depending on the process, particularly the temperature, but typically heavy metals and alkali predominantly remain in the bottom ash and chloride and salts are found in the fly ash. Of major interest, is the removal of chloride because it will affect the ash quality for utilization depending on the temperature, particle size, and liquid to solid ratio [58]. Up to $72.8 \%$ of $\mathrm{Ca}, \mathrm{Na}, \mathrm{K}$ and $\mathrm{Cl}$ were removed at 10:1 liquid/solid ratio and about 12.3\% removal was achieved for $\mathrm{Cr}$ [59]. The extraction of chloride can be described by the following mechanisms: physico-chemical dissolution of chloride crystals; internal diffusion of ions out of the solid matrix; external diffusion of ions in the surrounding stationary liquid-film around the ash particles [60]. For the recovery of heavy metal, the most significant factor is the control of $\mathrm{pH}$ followed by the liquid-to-solid ratio [61].

Ito pointed out that using $\mathrm{CO}_{2}$ bubbling enhances the removal of insoluble chloride in fly ash $[62,63]$. Although acid washing has high efficiency, it is neither economical nor environmentally friendly. Water washing could be a feasible alternative. However, one drawback is that a large amount of heavy metal will be released with the soluble salts [64]. Addition of chemical additives or controlling of the $\mathrm{pH}$, may overcome this problem [62,65-67].

\subsubsection{Leaching process}

This process aims to extract the heavy metals from ashes and to further recover them from the leachant solutions. In order to recover the heavy metals, their concentration must be high to ensure recovery. The leaching of heavy metals depends on the type of extraction solvent, the $\mathrm{pH}$, as well as the liquid-to-solid ratio [68-70].

According to Youcai, an increase in $\mathrm{pH}$ in the leaching solution will lower the leachability of heavy metals as insoluble hydroxides will form at higher $\mathrm{pH}$, and further suggested that using EDTA could be an effective agent for extracting heavy metals [34]. The extraction of heavy metals in MSW fly ash by using $\mathrm{HCl}$ is dependent on $\mathrm{pH}$ while chelating agents are independent of $\mathrm{pH}$. The maximum extraction of $\mathrm{Cr}, \mathrm{Cu}, \mathrm{Pb}$ and $\mathrm{Zn}$ in fly ash was obtained at $0.3-1 \%$ concentration of chelating agents [71,72]. Okada investigated the recovery of lead and zinc from fly ash: the content of recovery was acceptable, but the cost performance is not effective [7]. 
Water washing pre-treatment followed by bioleaching for heavy metal extraction from MSWI fly ash was demonstrated by Wang, and this green technology may be regarded as an alternative to conventional physicochemical methods for heavy metals removal in fly ash [73].

Different leaching agents were evaluated for MSWI fly ash leaching, in which it was concluded that using strong mineral acid results in high leaching of many elements; organic acids were not effective as leaching agents for metals; EDTA showed good removal of some metals like $\mathrm{Cu}$ and $\mathrm{Pb} ; \mathrm{NH}_{4} \mathrm{NO}_{3}$ was effective for $\mathrm{Cu}$ removal. Leaching is a good practice for promoting the use of MSWI fly ash as well as recovering the metals for re-use [74].

A hydrothermal process has been investigated for the temperature effect on metal extraction. The MSW ash was pre-treated by water washing and this effectively extracted $67 \%$ of $\mathrm{Na}, 76 \%$ of $\mathrm{K}$ and $48 \%$ of $\mathrm{Ca}$. Then the ash was treated by acid under hydrothermal conditions. Hydrothermal treatment accelerated the dissolution of the ash and promoted the reaction of acid with toxic metals such as $\mathrm{Cr}$, $\mathrm{Cd}$, and $\mathrm{Pb}$. The behavior of metals in ash followed hydrothermal leaching and hydrothermal precipitation under hydrothermal conditions. The optimum conditions suggested used hydrochloric acid with 10:1 liquid/solid ratio under $150{ }^{\circ} \mathrm{C}$ for five hours. Under hydrothermal conditions, the acid reacted with all metals in the ash while preferentially reacting with $\mathrm{Ca}$ at ambient conditions [75].

\subsubsection{Electrochemical process}

The objective of this process is to remove heavy metals and further recover them. The process involves the application of an electric potential to force the reduction/oxidation reactions on the surface of the cathode and anode. During the process, metals are deposited on the surface of cathode. Although the processes do not involve chemical addition, the efficiencies are quite low [76]. A combined treatment (washing + electrochemical process) was proposed by Ferreira and the results show that a great reduction of heavy metals in fly ash was achieved [77].

Figure 2. Principle of electrodialytic remediation (adapted from [77]).

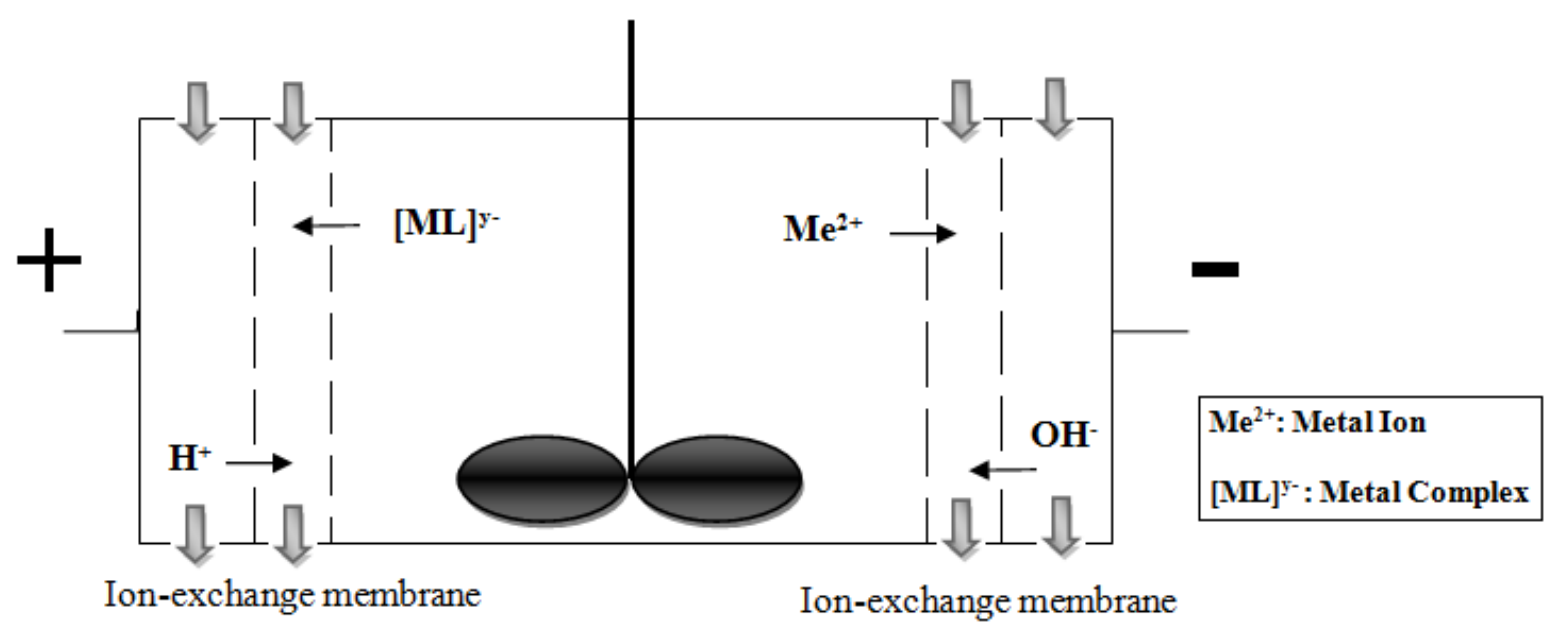




\subsection{Solidification/Stabilization (S/S) Methods}

The S/S process refers to those processes that use additive or binder to chemically and/or physically immobilize the hazardous content present in waste [78]. For stabilization, the objective is to minimize the solubility and toxicity of contaminates. For solidification, usually binders like cement are used to encapsulate the waste material in order to immobilize contaminates and reduce leachablity. The addition of Portland cement for S/S has already been used in many countries. However, the drawback is that this process is not suitable for treating soluble salts and long-term leaching will be an environmental problem. Also, the volume of waste will be increased (almost doubled) using this method. Thus, this method is much more suitable for treating highly toxic waste material $[79,80]$.

An integrated new stabilization technique was developed in four stages: the elimination of alkali chlorides by dissolution; addition of phosphoric acid; calcination; and solidification with cement. This process can destroy toxic organics, reduce heavy metal reactivity and solidify hazardous waste without exceeding the leaching limit [81].

A combined washing-immobilization process for treating fly ash was investigated by Mangialardi. The water washing treatment could remove significant amounts of chloride and sulfate from fly ash, promote the formation of a hydrate phase, and convert heavy metals into less reactive forms. Then the wastewater could be treated by reducing the $\mathrm{pH}$ to $6.5-7.5$; precipitation of aluminum hydroxide occurred, followed by the adsorption of cadmium, lead and zinc ions onto the floc particles of aluminum hydroxide. The treated fly ash was then incorporated into cement for further disposal [55]. Up to 75-90\% by weight of treated fly ash could be stabilized in cement without the risk of heavy metal leaching. Pre-treatment followed by S/S treatment can reduce the cost by about 50-63\% and make MSWI ash treatment more economically viable [82].

\subsection{Thermal Methods}

This process (Figure 3) can reduce the volume of waste by $60 \%$ or more; the product is more resistant to leaching, and is more environmentally stable for which applications such as secondary raw material may be easier. A temperature of approximately $1,400{ }^{\circ} \mathrm{C}$ will effectively destroy dioxins, furans and other toxic organic compounds [83]. Moreover, this type of treatment allows the reuse of melted slag as a resource [84]. As these methods involve high temperatures, the cost is usually high and the release of contaminants during melting is possible. Thus, further air pollution control is required. Ming-Yen suggested that water-washing followed by a sintering treatment can effectively result in detoxifying MSWI fly ash [85].

In Japan, vitrification and fusion of bottom ash is practiced at some facilities and the reuse of treated waste as secondary raw material has been demonstrated. The technology to recover heavy metals from fly ash for recycling to smelters is being developed and the process has proven to be commercially acceptable: almost $100 \%$ of toxic heavy metals in vitrification fly ash could be recovered and completely detoxified [86].

Vitrification treatment can transform highly inhomogeneous bottom ash into homogeneous glassy slag at a temperature between $1,360{ }^{\circ} \mathrm{C}$ and $1500{ }^{\circ} \mathrm{C}$. After the vitrification treatment, bottom ash contains on average $52.1 \%$ of $\mathrm{SiO}_{2}, 16.2 \%$ of $\mathrm{CaO}, 12.2 \%$ of $\mathrm{Al}_{2} \mathrm{O}_{3}$ and $7.7 \%$ of $\mathrm{Fe}_{2} \mathrm{O}_{3}$; while the recovered metal consists of about $82 \%$ of $\mathrm{Fe}, 12 \%$ of $\mathrm{Cu}$, and small percentages of $\mathrm{P}, \mathrm{C}$ and $\mathrm{S}$ and 
other minor alloying elements. The vitrified bottom ash has a lower leaching value than original bottom ash. This process is energy intensive, however, if environmental regulations become tighter in the future and the metal slag produced is market valuable, vitrification could be a sustainable option for ash treatment [87-90].

Figure 3. Structure of surface melting furnace, fixed bed type (Reproduced with permission from [84], published by Elsevier, 2000).

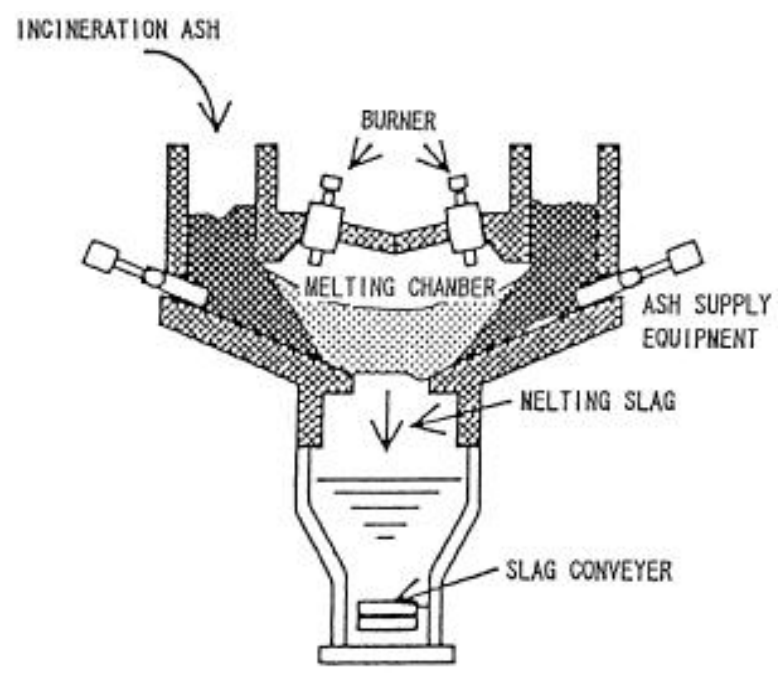

\subsection{Other Methods}

The Carbon-in-Pulp process is a process that can be used for the recovery of heavy metals from MSWI fly ash. Fly ash is stirred with $\mathrm{NaCl}$ for metal leaching, then granular activated carbon is utilized as an adsorbent for metal adsorption. The process is favored at low $\mathrm{pH}$ and is greatly influenced by the $\mathrm{NaCl}$ concentration $[91,92]$.

The accelerated carbonation process is a typical treatment method for contaminated soil and hazardous waste, giving reaction products with rapid hardening ability and that are monolithic. Carbonation treatment for MSWI ash was investigated by sequestration of $\mathrm{CO}_{2}$ into fresh ashes from an MSW incinerator. It showed good prospects for stabilizing lead and zinc as their mobility decreased with increasing partial pressure of $\mathrm{CO}_{2}$ and reaction time $[93,94]$. This treatment can reduce the $\mathrm{pH}$ to nearly neutral and lower the porosity, tortuosity, and pore area of the carbonated product. Also, the particles of fly ash after treatment become coarser due to agglomeration, which is beneficial for its utilization as an aggregate [95,96].

Muchova suggested the use of magnetic density separation for the recovery of high value metal such as silver and gold from MSWI bottom ash. The bottom ash has to be classified into different size fractions in order to separate precious metal. Magnetic density separation separates the fraction into a copper-zinc concentrate for the copper smelter and a precious metal concentrate for the precious metal smelter. The price of the 2-6 mm heavy non-ferrous fraction reaches up to 2,357-2,686 Euro/ton with the magnetic density separation, which is much higher than that without magnetic density separation (2,108 euro/ton). The process is only economically suitable for bottom ash larger than $2 \mathrm{~mm}$ and is still in the research stage [97]. 
Danish projects have shown that recovery was about $0.2-0.5 \%$ and $3.6-6.9 \%$ of bottom ash by weight for the non-magnetic metals and magnetic metals, respectively [98].

\section{Applications of MSWI Ashes}

After the above treatments, the ashes are much more usable. To determine the possibility of application, there are three main factors to address: suitability for processing, technical performance and environmental impact [99].

Table 9. Applications of MSWI ashes.

\begin{tabular}{lllll}
\hline Type & Application & Composition\% & Country & Authors \\
\hline BA & Aggregate in concrete & $\begin{array}{l}\text { up to 50\% } \\
\text { replace up to 15\% of }\end{array}$ & France & {$[100]$} \\
BA & Aggregate in concrete & cement & Slovenia & {$[101]$} \\
BA & Road base & & Spain & {$[39]$} \\
BA & Adsorbent for dyes & & India & {$[29]$} \\
BA & Concrete & & Italy & {$[102]$} \\
Mixed ash & Cement clinker & up to 50\% & Portugal & {$[103]$} \\
Mixed ash & Cement clinker & $44 \%$ & Japan & {$[31]$} \\
Mixed ash & Cement clinker & $15 \%$ & Taiwan & {$[30]$} \\
Mixed ash & Cement clinker & $1.75 \% \mathrm{FA} \mathrm{3.5 \%} \mathrm{BA}$ & Taiwan & {$[24]$} \\
Mixed ash & Aggregate in concrete & & Spain & {$[27]$} \\
FA & Concrete & $50 \%$ & France & {$[104]$} \\
FA & Eco cement & $50 \%$ & Japan & {$[105]$} \\
FA & Ceramic tile & & China & {$[26]$} \\
& Binder for stabilizing & & & \\
FA & sludge & $45 \%$ & China & {$[32]$} \\
& & $75 \% \mathrm{FA}, 20 \% \mathrm{SiO}_{2}$, & & \\
FA & Glass ceramic & $5 \% \mathrm{MgO}, 2 \% \mathrm{TiO}_{2}$ & Korea & {$[106]$} \\
FA & Glass ceramic (low melting temperature) & China & {$[28]$} \\
& & replace up to 30\% of & & \\
FA & Cement clinker & raw material & China & {$[107]$} \\
FA & Blended cement & up to 45\% & UK & {$[108]$} \\
\hline
\end{tabular}

Here, seven methods for the utilization of MSWI ash are reviewed, namely, cement and concrete production, road pavement, glasses and ceramics, agriculture, stabilizing agent, adsorbents and zeolite production.

\subsection{Cement and Concrete Production}

Since MSWI ash contains $\mathrm{CaO}, \mathrm{SiO}_{2}, \mathrm{Fe}_{2} \mathrm{O}_{3}$, and $\mathrm{Al}_{2} \mathrm{O}_{3}$, and the fact that a considerable amount of cement was used for the production of mortar and concrete, the composition of fly ash and bottom ash is similar to the composition of raw materials for cement production. Thus, it could be a possible replacement of raw material in Portland cement production [24,109,110]. R. Kikuchi has shown that 
the addition of MSWI ash for clinker production will shorten the setting time and decrease workability; he suggested that a delaying agent like gypsum should be added [103].

Cement production (Figure 4) indeed consumes huge quantities of energy and emits large amounts of carbon dioxide, which is the major cause of global warming industry activities. One of the advantages of using MSWI ash as cement raw material is the reduction in carbon dioxide emissions, thus minimizing the global warming effect. As a large amount of energy is used to decompose the calcium carbonate $\left(\mathrm{CaCO}_{3}\right)$ to lime $(\mathrm{CaO})$, a huge amount of carbon dioxide is emitted during the process. Due to the fact that MSWI bottom ash and fly ash is composed of lime instead of calcium carbonate, it can reduce the carbon dioxide emission. There are several technical problems discouraging this application; the high chloride content will affect the product quality, and the cycling effect in the cement kilns will cause rapid clogging and corrosion inside the heat exchangers $[111,112]$. The high concentration of heavy metals will also be an environmental concern.

Pre-treatment of fly ash is recommended to remove the chloride and heavy metals content, also the quantities of MSWI ash added to the process should be carefully controlled in order to ensure the process safety as well as product quality $[58,62,113]$.

Figure 4. Schematic Diagram of the Cement Production Process.

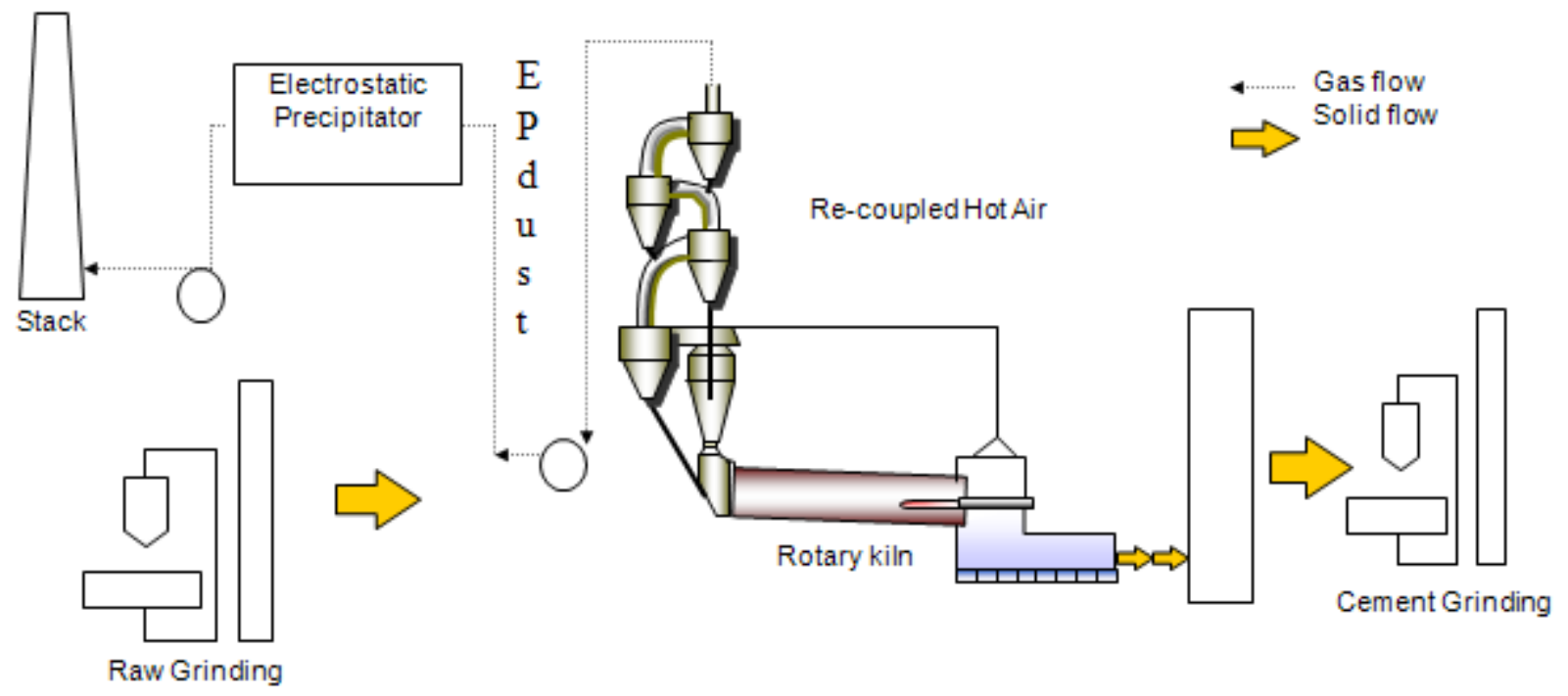

For the hydration behavior of cement clinker, it is found that alkali metal content enhances hydration and contents of $\mathrm{Zn}, \mathrm{Pb}$ and $\mathrm{Cd}$ retards the rate of hydration of cement. After washing pre-treatment of MSWI ash, the alkali metal content is reduced and the hydration rate of washed MSW ash containing clinkers is lower than the raw MSWI ash containing clinkers [31,114-116]. Fly ash contains high chloride and sulfate content, which reveal the formation of a ettringite phase in the hydration period, thus the hydration reaction slows down with the increasing fly ash content [117].

Based on S/S technology, the MSWI fly ash can be potentially applied as a replacement of cement or as an aggregate [118]. The addition of up to 50\% treated fly ash will not affect the strength and hardness, and the leaching property is acceptable for the use in road construction. However, the long-term durability has not yet been determined [104,119]. 
It is possible to use MSWI bottom ash as concrete aggregate. The results show that treated (immersion in sodium hydroxide for 15 days) bottom ash can replace up to $50 \%$ of gravel in concrete without affecting the durability. Cracking and swelling occur if the ash is not treated, due to the reaction between metallic aluminum and cement. MSWI fly ash could also be used as lightweight concrete aggregate by processing into pellets. This could be suitable for non-structural applications such as interior walls for insulating purposes [100]. Also, the use of cement-solidified MSWI fly ash has been proved to be suitable for safety reuse as artificial aggregate in Portland cement mortars. It showed low leaching rates of heavy metals, high compressive strengths (up to $36 \mathrm{~N} / \mathrm{mm}^{2}$ after 90 days of curing) without delay in mechanical strength development for the mortars incorporating into aggregate [120]. Water washing treatment can enhance the reuse of MSW fly ash as a concrete aggregate, under the condition of a compact pressure of $28 \mathrm{~N} / \mathrm{mm}^{2}$ and sintering temperature of $1,140{ }^{\circ} \mathrm{C}$ for 60 minutes [121].

The leaching problem is the major environmental concern of this application. Although many results show that the heavy metal leaching is not significant, unexpected heavy metal leaching may occur when the structure is demolished or comes in contact with rain [122].

Attempts at using large amounts of ash in cement clinker have been developed in Japan: this is known as ecocement [31,105]. Another process, known as the Co-combustion process [15,111], initially uses the energy from MSW incineration to calcine limestone to lime in Portland cement production and then uses a blend of fly ash and bottom ash as part of the clinker raw meal feed.

\subsection{Road Pavement}

A typical road pavement consists of several layers, which are composed of different types of materials. Figure 5 shows the structure of a road pavement. The uppermost layer of a sealed pavement is wearing course. It should be even, durable and highly skid resistant. The most common materials for wearing courses are bituminous surface dressing and asphalt concrete. The layer below the wearing course is the base course, which is the main load-spreading layer. The base may consist of premixed asphalt, cement concrete, graded granular gravel, crushed rock, or materials stabilized with lime or cement. The layer below the base course is the sub-base, which is usually constructed from natural gravel or from materials stabilized with cement or lime. The lowest layer is subgrade, which is the soil acting as a foundation for the pavement [123].

Figure 5. Typical pavement structure.

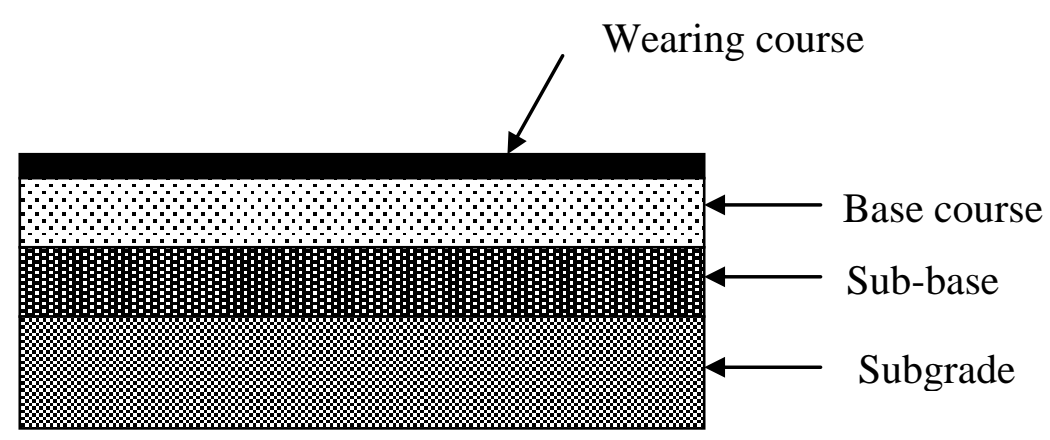


A possible way to reuse the MSWI bottom ash is to replace the materials in the base course and sub-base. The use of MSWI bottom ash in road pavement provides a simple and direct method for reuse of the incineration ash [124]. Several road sections have utilized MSWI bottom ash in road construction [125-127]. A test road was built in Sweden and the bottom ash was used as a sub-base material [128]. It was found that substituting gravel in the road base with the bottom ash did not affect the release of $\mathrm{Ca}, \mathrm{Co}, \mathrm{Fe}, \mathrm{Mn}, \mathrm{Ni}, \mathrm{NO}_{3}-\mathrm{N}$ (nitrate-nitrogen) and $\mathrm{Pb}$ to the environment. Another three-year study on the utilization of MSWI bottom ash in road pavement in France, showed the concentrations of heavy metals, fluorides and $\mathrm{pH}$ values in the leachate were below the limits authorized for potable water [125]. It indicated that it is safe to use bottom ash for road construction.

In Japan, a melting and stone production plant was built to utilize MSWI fly ash for stone production. One of the applications of the stone produced is for permeable-pavements, with $85 \mathrm{wt} \%$ of the grounded stone. This technology has been proven to be commercially applicable, and in 1999, about $1800 \mathrm{~m}^{2}$ of pavement blocks were used for a park in Chiba Prefecture [129].

The main concern of these applicants is that the leaching of contaminants into soil and groundwater raise an environmental problem. A possible solution could be pre-treatment of ash by washing to reduce the concentration of contaminants $[39,126]$. It has been reported that the use of fly ash stabilized by cement, which would be used as a road base construction material, did not meet the leaching standards for construction material. In contrast, the washed stabilized fly ash can meet the most severe standards [56].

\subsection{Glasses, Glass-Ceramics and Ceramics}

MSWI bottom ash and fly ash has also been used as raw materials for the production of glasses, glass-ceramics and ceramics under high temperature $\left(>1,000{ }^{\circ} \mathrm{C}\right)$. As MSWI bottom ash and fly ash contains high content of $\mathrm{SiO}_{2}, \mathrm{Al}_{2} \mathrm{O}_{3}$ and $\mathrm{CaO}$, it is possible to use MSWI bottom and fly ash to replace part of the clay for the production of ceramics without pre-treatment. Andreola et al. has studied the feasibility of using MSWI bottom ash and fly ash for the production of ceramic tile body [130]. They found that introducing up to $20 \mathrm{wt} \%$ of bottom ash into the ceramic body did not substantially change the mineralogical and thermal behaviors of the ceramic body. However, the use of fly ash brought problems in the properties of the ceramic body produced and it may due to high chloride and organic content in the fly ash. Haiying et al. showed different results for the utilization of fly ash in the production of ceramic tiles [26]. They showed that with 20\% MSWI fly ash added, the ceramic tile register a high compressive strength and low water absorption after $960{ }^{\circ} \mathrm{C}$ sintering. The amount of toxic heavy metal leaching was reduced to one-tenth of that in fly ash. The MSWI ash can be used for the production of ceramic tiles and acceptable durability is obtained even when the tiles contain $50 \%$ of MSWI ash.

Vitrification, which is one of the most efficient techniques employed to treat hazardous wastes, is able to fix heavy metals or toxic substances into the amorphous structure of glass. At the same time, the toxic substances such as dioxins decompose when melted above $1,300{ }^{\circ} \mathrm{C}$. The vitrified ash is used as road base material, blasting grit, embankments, in the production of construction and decorative materials like ceramic tiles, pavement bricks and water-permeable blocks. Cheng observed that the 
domestic waste incinerator fly ash sintered and heated at $950{ }^{\circ} \mathrm{C}$ for two hours has good potential to manufacture light-weight aggregates or bricks for engineering applications [23].

Glass-ceramics are fine-grained polycrystalline materials formed when glasses of suitable compositions are heat-treated, and thus undergo controlled crystallization to the lower energy, crystalline state. The mechanical and thermal properties of glass-ceramics are superior to those of the parent glass. Due to its distinct properties, the glass-ceramics find a wide variety of applications. Numerous silicate based wastes have been considered for the production of glass-ceramics [131]. It has been found that glass produced from the vitrification of incineration ash is suitable for the production of glass-ceramic materials due to its mechanical and thermal characteristics [25]. Vitrified ashes have been successfully used as raw material for production of glass-ceramics. [22,28,132,133] and the properties of the glass-ceramics were greatly affected by the heat treatment time and temperature. Yang demonstrated the reuse of MSWI fly ash for glass-ceramic production at a relatively low melting temperature by the use of additives. The melting temperature can be decrease significantly from $1,500{ }^{\circ} \mathrm{C}$ to $1,200{ }^{\circ} \mathrm{C}$, which makes the process less energy intensive and environmentally friendly as less energy is consumed [28].

Glasses obtained from the vitrification process show lower percentages of metals release and less ion release compared to incinerator ash [134]. However, the exposure of the glass to water may leach toxic substances from the glass matrix. The corrosion behavior of glass and glass-ceramic made of MSWI fly ash was investigated by Park and Heo [135]. It was found that the leaching of heavy metal ions from the glass and glass-ceramic was well below environmental regulations.

\subsection{Agriculture}

Nitrogen, phosphorous and potassium are the three main nutrients for plant growth. Both MSWI fly ash and bottom ash have been tested to provide nutrients to soil in agricultural applications. As MSWI bottom ash contains acceptable amounts of phosphorous and potassium, it can be used as a partial replacement of commercial fertilizers. Also, the lime in fly ash can reduce the soil acidity, thus it can be used as a liming agent. However, there are many restrictions for these applications. The heavy metals in bottom ash will be toxic to plants and animals; the high salts content will induce salt stress in plants; the $\mathrm{pH}$ value in soil will affect the mobility of elements; and the leaching of heavy metal into ground water will cause environmental concerns. As a result, more research studies have to be done in this field [136].

One of the studies showed that MSWI fly ash, bottom ash and combined ash can influence plant growth in a positive manner. Growth of alfalfa and Swiss chard in ash-amended soils was similar than that in soils amended with phosphorous and potassium fertilizer, indicating that MSW ash can supply essential nutrients for plant growth. However, the high Mo concentrations and uptake of Cd was significant enough to raise concern if the plant tissue was to be ingested by cattle, sheep, and swine. Also, the high soluble salt content can cause problems with sensitive plants under high amounts of ash amendments [137]. 


\subsection{Stabilizing Agent}

MSWI fly ash has been examined for possible use as a landfill interim cover [138]. The co-digestion of MSW with the proper amount of MSWI fly ash, could facilitate bacterial activity, digestion efficiency as well as methane gas production rate. It is found that the toxic heavy metals and released ions such as chloride do not have significant impact on anaerobic digestion.

Furthermore, the potential for utilization of MSWI fly ash as S/S binder to treat heavy metal-bearing sludge has been examined. An optimum mix comprising $45 \%$ of fly ash, $50 \%$ of sludge and $5 \%$ of cement could provide the required stabilization and solidification for disposal. This co-disposal approach can minimize the enlargement of landfill volume and effectively stabilize the heavy metals [32].

\subsection{Adsorbents}

Adsorption techniques are widely used to remove pollutants from waters and people are looking for low-cost alternatives to activated carbon [139-141]. Bottom ash from MSWI has been employed for removing dye and heavy metals from wastewater $[29,142]$. One of the major concerns for using incinerator ash for wastewater treatment is the leachability of heavy metals, as the presence of heavy metals in the water is a serious problem due to their high toxicity. The use of MSW fly ash as the adsorbent is less common than the bottom ash [143]. This may due to the fact there are more toxic heavy metals in the leachate of fly ash, which reduces the possibility to use it as an adsorbent. In contrast, the bottom ash rarely releases hazardous heavy metal in the leachate.

The cation exchange capacity of MSWI bottom ash is the total amount of exchangeable capacity (milliequivalents per 100 grams of adsorbing materials). It is important to compare adsorption capacities for different materials. It has been found that the cation exchange capacity (CEC) greatly depends on the particle size of the bottom ash. The adsorption characteristics of heavy metals by different MSW bottom ash particle sizes has been investigated, the smaller the particle size, the higher the CEC value and surface area. The adsorption rate of heavy metals increases with decreasing bottom ash particle size, which means the adsorption rate is proportional to the particle size and specific surface area of bottom ash. Decreasing the particle size from +120 to -100 mesh increases the CEC of the bottom ash from 8.0 to $24.6 \mathrm{meq} / 100 \mathrm{~g}$. It has been used for removing $\mathrm{Ni}$ and $\mathrm{Cu}$ from plating rinse water with $\mathrm{pH}$ of 3.8 [142].

Bottom ash was also used as an adsorbent for the removal of dyes from wastewater. Gupta et al. [29] studied the removal of dyes from wastewater using bottom ash from MSWI from Belgium. The results showed that the removals of dyes are up to $98 \%$ by the batch method and the adsorption capacity is comparable to other available adsorbents. The optimum $\mathrm{pH}$ for the dye adsorption ranged from 5 to 8 and depended on the chemical structure of the dye molecules. The adsorption capacities of alizarin yellow, fast green and methyl violet onto the bottom ash were found to be $0.083,0.068,0.043 \mathrm{mmol} / \mathrm{g}$ respectively. It suggests that the low-cost bottom ash can be used for the removal of dye from wastewater.

Besides use as an adsorbent for wastewater treatment, the bottom ash was also used for gas purification. The bottom ash was used for the removal of reduced sulfur compounds from a real landfill gas [144]. It was found that the bottom ash was able to remove hydrogen sulfide, methyl 
mercaptan, dimethyl sulfide without affecting the energetic content of the landfill gas as methane is not retained in the bottom ash. It was found that one kilogram bottom ash is able to sequestrate more than $3.0 \mathrm{~g}$ of hydrogen sulfide, $44 \mathrm{mg}$ of methyl mercaptan, and $86 \mathrm{mg}$ of dimethyl sulfide. Hydrogen sulfide and methyl mercaptan retention is probably due to acid-basic reactions involving sulfur mineralization under the form of low solubility metal sulfides. The retention mechanism for dimethyl sulfide is most likely by physical adsorption.

Several studies have reported the use of fly ash as an adsorbent for dyes [143,145], heavy metals [146-149] and organics [150,151]. One of the advantages of using fly ash for wastewater treatment is that the fly ash has neutralizing ability; therefore the fly ash can be used in the treatment of acidic industrial wastewater. It is because excess of lime was always added to remove the $\mathrm{HCl}$ and $\mathrm{SO}_{2}$ in the flue gas in MSW incinerators [113]. However, the final $\mathrm{pH}$ of the treated water greatly depends on the liquid to solid ratio used.

\subsection{Zeolite Production}

Both synthetic and natural zeolites have been employed for environmental and catalytic applications $[152,153]$. As the main components of coal fly ash are $\mathrm{SiO}_{2}$ and $\mathrm{Al}_{2} \mathrm{O}_{3}(70-80 \%)$, which exhibit a similar composition to zeolite, coal fly ash has been used as a raw material to synthesize zeolite-like materials [154,155]. Although, MSWI fly ash has a lower content of $\mathrm{SiO}_{2}$ and $\mathrm{Al}_{2} \mathrm{O}_{3}$ (15-30\%), different types of zeolites have been synthesized by utilizing the MSWI fly ash by fusion or hydrothermal process [156,157]. The surface area and CEC of the zeolite produced was found significantly higher than the raw fly ash. Although the CEC of the zeolite produced $(90 \mathrm{meq} / 100 \mathrm{~g})$ is lower than the commercial zeolite (200-300 meq/100 g), it shows the feasibility of using MSWI fly ash to synthesis zeolite. However, it was found that the residual liquid after the synthesize contains high concentrations of heavy metals such as $\mathrm{Pb}$ and $\mathrm{Zn}$ needs further treatment before discharge [156].

As MWSI fly ash has a lower content of $\mathrm{SiO}_{2}$ and $\mathrm{Al}_{2} \mathrm{O}_{3}$, a mixed fly ash of MSW and coal may become a feasible way for improving the quality of the zeolite and the use of MSW ash for zeolite production. Fan et al. used the waste fly ash from MSW and coal co-combustion power plant to synthesize zeolites [158]. They demonstrated that the properties of the zeolite products mainly depend on $\mathrm{NaOH}$ concentration, reaction temperature and crystallization time. The development of Zeolite $\mathrm{X}$ is favorable under development at lower $\mathrm{NaOH}$ /ash ratio and operating temperature and zeolite $\mathrm{HS}$ can be synthesized at higher $\mathrm{NaOH} /$ ash ratio and operating temperature [158]. The monolayer adsorption capacities of $\mathrm{Zn}^{2+}$ onto the zeolite produced was found to be $121.97 \mathrm{mg} / \mathrm{g}$, which is higher than coal fly ash based zeolite. Fan et al. also modified the zeolite with iron (II) ions and used this product for Arsenic (V) adsorption as hydrated iron has a high affinity towards arsenic oxyanions [149]. The adsorption capacity for As (V) was $13.04 \mathrm{mg} / \mathrm{g}$. The adsorption capacity of modified zeolite, developed from fly ash, is comparable to the capacities of many of the other adsorbents [159]. Zeolite was also successfully synthesized by alkaline hydrothermal treatment of MSWI bottom ash; however, the use of bottom ash from MSWI for zeolite synthesis is less common than using fly ash [160]. 


\section{Conclusions}

Many of the applications of MSWI ash are still under investigation. The environmental and technical problems have discouraged the reuse of MSWI ash. Even though pre-treatment increases the total cost, the treatment process enables the ashes to be reused. Any one of the applications would be a great contribution in minimizing the waste and providing an alternative to landfill.

\section{References}

1. Banar, M.; Zkan, A. Characterization of the municipal solid waste in Eskisehir City, Turkey. Environ. Eng. Sci. 2008, 25, 1213-1219.

2. Moy, P.; Krishnan, N.; Ulloa, P.; Cohen, S.; Brandt-Rauf, P.W. Options for management of municipal solid waste in New York City: A preliminary comparison of health risks and policy implications. J. Environ. Manag. 2008, 87, 73-79.

3. Johannessen, K.M. The regulation of municipal waste incineration ash: A legal review and update. J. Hazard. Mater. 1996, 47, 383-393.

4. Ecke, H.; Sakanakura, H.; Matsuto, T.; Tanaka, N.; Lagerkvist, A. State-of-the-art treatment processes for municipal solid waste incineration residues in Japan. Waste Manag. Res. 2000, 18, 41-51.

5. Sakai, S.I. Municipal solid waste management in Japan. Waste Manag. 1996, 16, 395-405.

6. Jung, C.H.; Matsuto, T.; Tanaka, N.; Okada, T. Metal distribution in incineration residues of municipal solid waste (MSW) in Japan. Waste Manag. 2004, 24, 381-391.

7. Okada, T.; Tojo, Y; Tanaka, N.; Matsuto, T. Recovery of zinc and lead from fly ash from ash-melting and gasification-melting processes of MSW-Comparison and applicability of chemical leaching methods. Waste Manag. 2007, 27, 69-80.

8. Li, M.; Xiang, J.; Hu, S.; Sun, L.S.; Su, S.; Li, P.S.; Sun, X.X. Characterization of solid residues from municipal solid waste incinerator. Fuel 2004, 83, 1397-1405.

9. Sawell, S.E.; Chandler, A.J.; Eighmy, T.T.; Hartln, J.; Hjelmar, O.; Kosson, D.; Van Der Sloot, H.A.; Vehlow, J. An international perspective on the characterisation and management of residues from MSW incinerators. Biomass Bioenerg. 1995, 9, 377-386.

10. Hjelmar, O. Waste management in Denmark. Waste. Manag. 1996, 16, 389-394.

11. Reijnders, L. Disposal, uses and treatments of combustion ashes: A review. Resour. Conserv. Recycl. 2005, 43, 313-336.

12. Sakai, S.; Sawell, S.E.; Chandler, A.J.; Eighmy, T.T.; Kosson, D.S.; Vehlow, J.; Van Der Sloot, H.A.; Hartlen, J.; Hjelmar, O. World trends in municipal solid waste management. Waste Manag. 1996, 16, 341-350.

13. Skodras, G.; Grammelis, P.; Kakaras, E.; Karangelos, D.; Anagnostakis, M. ; Hinis, E. Quality characteristics of Greek fly ashes and potential uses. Fuel Process. Technol. 2007, 88, 77-85.

14. Incineration of municipal solid waste. A state-of-the-art report. Pub. Works 1990, 121, 1-5.

15. Lee, V.K.C.; Kwok, K.C.M.; Cheung, W.H.; McKay, G. Operation of a municipal solid waste co-combustion pilot plant. Asia-Pac. J. Chem. Eng. 2007, 2, 631-639.

16. Integrated Waste Management Facilities; Available online: http://www.epd.gov.hk/epd/english/ environmentinhk/waste/prob_solutions/WFdev_IWMFtech.html (acessed on 10 December 2009). 
17. Chang, M.B.; Ku, S.R. Fates and partitioning of heavy metals in municipal solid waste incineration process. Toxicol. Environ. Chem. 1998, 67, 161-169

18. Eusden, J.D.; Eighmy, T.T.; Hockert, K.; Holland, E.; Marsella, K. Petrogenesis of municipal solid waste combustion bottom ash. App. Geochem. 1999, 14, 1073-1091.

19. Dhadse, S.; Kumari, P.; Bhagia, L.J. Fly ash characterization, utilization and government initiatives in India-A review. J. Sci. Ind. Res. 2008, 67, 11-18.

20. He, P.J.; Zhang, H.; Zhang, C.G.; Lee, D.J. Characteristics of air pollution control residues of MSW incineration plant in Shanghai. J. Hazard. Mater. 2004, 116, 229-237.

21. Alba, N.; Gasso, S.; Lacorte, T.; Baldasano, J.M. Characterization of municipal solid waste incineration residues from facilities with different air pollution control systems. J. Air Waste Manage. Assoc. 1997, 47, 1170-1179.

22. Romero, M.; Rincon, J.M.; Rawlings, R.D.; Boccaccini, A.R. Use of vitrified urban incinerator waste as raw material for production of sintered glass-ceramics. Mater. Res. Bulletin 2001, 36, 383-395.

23. Cheng, T.W.; Chen, Y.S. Characterisation of glass ceramics made from incinerator fly ash. Ceram. Int. 2004, 30, 343-349.

24. Pan, J.R.; Huang, C.; Kuo, J.J.; Lin, S.H. Recycling MSWI bottom and fly ash as raw materials for Portland cement. Waste Manag. 2008, 28, 1113-1118.

25. Andreola, F.; Barbieri, L.; Hreglich, S.; Lancellotti, I.; Morselli, L.; Passarini, F.; Vassura, I. Reuse of incinerator bottom and fly ashes to obtain glassy materials. J. Hazard. Mater. 2008, 153, 1270-1274.

26. Haiying, Z.; Youcai, Z.; Jingyu, Q. Study on use of MSWI fly ash in ceramic tile. J. Hazard. Mater. 2007, 141, 106-114.

27. Gines, O.; Chimenos, J.M.; Vizcarro, A.; Formosa, J.; Rosell, J.R. Combined use of MSWI bottom ash and fly ash as aggregate in concrete formulation: Environmental and mechanical considerations. J. Hazard. Mater. 2009, 169, 643-650

28. Yang, J.; Xiao, B.; Boccaccini, A.R. Preparation of low melting temperature glass-ceramics from municipal waste incineration fly ash. Fuel 2009, 88, 1275-1280.

29. Gupta, V.K.; Ali, I.; Saini, V.K; Van Gerven. T.; Van Bruggen, B.D.; Vandecasteele, C. Removal of dyes from wastewater using bottom ash. Ind. Eng. Chem. Res. 2005, 44, 3655-3664.

30. Shih, P.H.; Chang, J.E.; Chiang, L.C. Replacement of raw mix in cement production by municipal solid waste incineration ash. Cem. Concr. Res. 2003, 33, 1831-1836.

31. Saikia, N.; Kato, S.; Kojima, T. Production of cement clinkers from municipal solid waste incineration (MSWI) fly ash. Waste Manag. 2007, 27, 1178-1189.

32. Qian, G.; Cao Y.; Chui, P.; Tay, J. Utilization of MSWI fly ash for stabilization/solidification of industrial waste sludge. J. Hazard. Mater. 2006, 129, 274-281.

33. Waste and Recycled Materials Use in the Transportation Industry. In National Cooperative Highway Research Program; Transportation Research Board, National Research Council: Washington, DC, USA, 2000.

34. Youcai, Z.; Lijie, S.; Guojian, L. Chemical stabilization of MSW incinerator fly ashes. J. Hazard. Mater. 2002, 95, 47-63. 
35. Chang, C.Y.; Wang, C.F.; Mui, D.T.; Cheng, M.T.; Chiang, H.L. Characteristics of elements in waste ashes from a solid waste incinerator in Taiwan. J. Hazard. Mater. 2008, 165, 766-773.

36. Wu, H.Y.; Ting, Y.P. Metal extraction from municipal solid waste (MSW) incinerator fly ash-Chemical leaching and fungal bioleaching. Enzyme Microb. Technol. 2006, 38, 839-847.

37. Hjelmar, O. Disposal strategies for municipal solid waste incineration residues. J. Hazard. Mater. 1996, 47, 345-368.

38. The Research on the Utilization of MSWI Residues(II); Taiwan Environmental Protection Agency: Taipei, Taiwan, 2004.

39. Forteza, R.; Far, M.; Segui, C.; Cerda, V. Characterization of bottom ash in municipal solid waste incinerators for its use in road base. Waste. Manag. 2004, 24, 899-909.

40. Municipal Solid Waste Incinerator Residues Study; Environmental Sciemce 67; Elsevier: Amsterdam, The Nertherland, 2000.

41. Ferreira, C.; Ribeiro, A.; Ottosen. L. Heavy Metals in MSW Incineration Fly Ashes. J. Phys. IV 2003, 17, 463-466.

42. Lima, A.T.; Ottosen L.M.; Pedersen, A.J.; Ribeiro, A.B. Characterization of fly ash from bio and municipal waste. Biomass Bioenerg. 2008, 32, 277-282.

43. Hinton, W.S.; Lane, A.M. Characteristics of municipal solid waste incinerator fly ash promoting the formation of polychlorinated dioxins. Chemosphere 1991, 22, 473-483.

44. Bie, R.; Li, S.; Wang, H. Characterization of PCDD/Fs and heavy metals from MSW incineration plant in Harbin. Waste Manag. 2007, 27, 1860-1869.

45. Lee, V.K.C.; Cheung, W.H.; McKay, G. PCDD/PCDF reduction by the co-combustion process. Chemosphere 2008, 70, 682-688.

46. McKay, G. Dioxin characterisation, formation and minimisation during municipal solid waste (MSW) incineration: Review. Chem. Eng. J. 2002, 86, 343-368.

47. Choi, K.I.; Lee, D.H. PCDD/DF in leachates from Korean MSW landfills. Chemosphere 2006, 63, 1353-1360.

48. Zhang, H.J.; Ni, Y.W.; Zhang, X.P.; Zhang, Q.; Zhao, L.; Zhang, N.; Chen, J.P. PCDD/F formation and its mass balance in a MSW incineration system. Environ. Sci. 2008, 29, 1133-1137.

49. Jin, Y.; Tian H.; Nie; Y.; Yin, H.; Hai, Y.; Chen, Z. Dioxins contents in fly ash of MSW incinerator in three cities. Enviorn. Sci. 2003, 24, 21-25.

50. Shin, K.J.; Chang, Y.S. Characterization of polychlorinated dibenzo-p-dioxins, dibenzofurans, biphenyls, and heavy metals in fly ash produced from Korean municipal solid waste incinerators. Chemosphere 1999, 38, 2655-2666.

51. Institute, J.S.R.R. Direct speciation of copper, lead, antimony, zinc and chromium in municipal solid waste incinerator fly ash by X-ray absorption fine structure spectroscopy. Res. Front. 2001, 8, 65-67.

52. Chang, M.B.; Chung, Y.T. Dioxin contents in fly ashes of MSW incineration in Taiwan. Chemosphere 1998, 36, 1959-1968.

53. Chang, M.B.; Huang, T.F. Dioxin contents in fly ash from large-scale MSW incinerators in Taiwan. Chemosphere 1999, 39, 2671-2680.

54. Quina, M.J.; Bordado, J.C.; Quinta-Ferreira, R.M. Treatment and use of air pollution control residues from MSW incineration: An overview. Waste Manag. 2008, 28, 2097-2121. 
55. Mangialardi, T. Disposal of MSWI fly ash through a combined washing-immobilisation process. J. Hazard. Mater. 2003, 98, 225-240.

56. Mulder, E. Pre-treatment of mswi fly ash for useful application. Waste Manag. 1996, 16, 181-184.

57. Wilewska-Bien, M.; Lundberg, M.; Steenari, B.M.; Theliander, H. Treatment process for MSW combustion fly ash laboratory and pilot plant experiments. Waste Manag. 2007, 27, 1213-1224.

58. Boghetich, G.; Liberti L.; Notarnicola M.; Palma, M.; Petruzzelli, D. Chloride extraction for quality improvement of municipal solid waste incinerator ash for the concrete industry. Waste Manag. Res. 2005, 23, 57-61.

59. Jiang, Y.; Xi, B.; Li, X.; Zhang, L.; Wei, Z. Effect of water-extraction on characteristics of melting and solidification of fly ash from municipal solid waste incinerator. J. Hazard. Mater. 2009, 161, 871-877.

60. Helfferich, F. Ion Eexchange; McGraw Hill: New York, NY, USA, 1962.

61. Aguiar del Toro, M.; Calmano, W.; Ecke, H. Wet extraction of heavy metals and chloride from MSWI and straw combustion fly ashes. Waste Manag. 2009, 29, 2494-2499.

62. Ito, R.; Dodbiba, G.; Fujita, T.; Ahn, J.W. Removal of insoluble chloride from bottom ash for recycling. Waste Manage. 2008, 28, 1317-1323.

63. Ito, R.; Fujita, T.; Sadaki, J.; Matsumoto, Y.; Ahn, J.W. Removal of chloride in bottom ash from the industrial and municipal solid waste incinerators. Int. J. Soc. Mater. Eng. Res. 2006, 13, 70-74.

64. Kirby, C.S.; Rimstidt, J.D. Interaction of municipal solid waste ash with water. Environ. Sci. Technol. 1994, 28, 443-451.

65. Zhu, F.; Takaoka, M.; Oshita, K.; Takeda, N. Comparison of two types of municipal solid waste incinerator fly ashes with different alkaline reagents in washing experiments. Waste Manag. 2009, 29, 259-264.

66. Zhu, F.; Takaoka, M.; Shiota, K.; Oshita, K.; Kitajima, Y. Chloride chemical form in various types of fly ash. Environ. Sci. Technol. 2008, 42, 3932-3937.

67. Zhu, F.; Takaoka M.; Oshita K.; Kitajima, Y.; Inada, Y.; Morisawa, S; Tsuno, H. Chloride behavior in raw fly ash washing experiments. J. Hazard. Mater. 2010, 178, 547-552.

68. Ferreira, C.; Ribeiro, A.B.; Ottosen. L.M. Study of Different Assisting Agents for the Removal of Heavy Metals from MSW Fly Ashes. In Waste Management and the Environment; Elsevier: Cadiz, Spain, 2002.

69. Goldberg, D. Recycling metal from MSW incinerator ash. Recycl. Today 1988, 26, 34-40.

70. Mizutani, S.; Yoshida T.; Sakai, S.I; Takatsuki, H. Release of metals from MSW I fly ash and availability in alkali condition. Waste Manag. 1996, 16, 537-544.

71. Hong, K.J.; Tokunaga, S.; Ishigami, Y.; Kajiuchi, T. Extraction of heavy metals from MSW incinerator fly ash using saponins. Chemosphere 2000, 41, 345-352.

72. Hong, K.J.; Tokunaga, S.; Kajiuchi, T. Extraction of heavy metals from MSW incinerator fly ashes by chelating agents. J. Hazard. Mater. 2000, 75, 57-73.

73. Wang, Q.; Yang, J.; Wu, T. Effects of water-washing pretreatment on bioleaching of heavy metals from municipal solid waste incinerator fly ash. J. Hazard. Mater. 2009, 162, 812-818. 
74. Karlfeldt Fedje, K.; Ekberg C.; Skarnemark, G.; Steenari, B.M. Removal of hazardous metals from MSW fly ash-An evaluation of ash leaching methods. J. Hazard. Mater. 2010, 173, 310-317.

75. Zhang, F.S.; Itoh, H. Extraction of metals from municipal solid waste incinerator fly ash by hydrothermal process. J. Hazard. Mater. 2006, 136, 663-670.

76. Ferreira, C.; Jensen P.; Ottosen, L; Ribeiro, A. Removal of selected heavy metals from MSW fly ash by the electrodialytic process. Eng. Geo. 2005, 77, 339-347.

77. Ferreira, C.D.; Jensen, P.; Ottosen, L.; Ribeiro, A. Preliminary treatment of MSW fly ash as a way of improving electrodialytic remediation. J. Environ. Sci. Health Part A: Toxic/Hazard. Subst. Environ. Eng. 2008, 43, 837-843.

78. Wiles, C.C. Municipal solid waste combustion ash: State-of-the-knowledge. J. Hazard. Mater. 1996, 47, 325-344.

79. Auer, S.; Kuzel H.J.; Pollmann, H.; Sorrentino, F. Investigation on MSW fly ash treatment by reactive calcium aluminates and phases formed. Cem. Concr. Res. 1995, 25, 1347-1359.

80. Alba, N.; Vázquez E.; Gasso, S.; Baldasano, J.M. Stabilization/solidification of MSW incineration residues from facilities with different air pollution control systems. Durability of matrices versus carbonation. Waste Manag. 2001, 21, 313-323.

81. Derie, R. A new way to stabilize fly ash from municipal incinerators. Waste Manag. 1996, 16, 711-716.

82. Mangialardi, T.; Paolini, A.E.; Polettini, A.; Sirini, P. Optimization of the solidification/stabilization process of MSW fly ash in cementitious matrices. J. Hazard. Mater. 1999, 70, 53-70.

83. Lima, R.; Saloca, M. Technical note: An effective thermal technology for the detoxification of MSW fly ash. Int. J. Environ. Technol. Manage. 2003, 3, 212-218.

84. Sakai, S.I.; Hiraoka, M. Municipal solid waste incinerator residue recycling by thermal processes. Waste Manag. 2000, 20, 249-258.

85. Wey, M.Y.; Liu, K.Y.; Tsai, T.H.; Chou, J.T. Thermal treatment of the fly ash from municipal solid waste incinerator with rotary kiln. J. Hazard. Mater. 2006, 137, 981-989.

86. Izumikawa, C. Metal recovery from fly ash generated from vitrification process for MSW ash. Waste Manag. 1996, 16, 501-507.

87. Xiao, Y.; Harskamp, R.G.; Yang. Y. Pre-Washing and Vitrification of Fly Ash from a Municipal Solid Waste Incinerator. In Proceedings of the 2008 Global Symposium on Recycling, Waste Treatment and Clean Technology (REWAS 2008), Cancun, Mexico, 12-15 October 2008.

88. Polettini, A.; Pomi, R.; Sirini. P. Vitrification and Sintering for MSWI Fly Ash Inertization as Alternatives to Conventional Stabilization Treatments. In Proceedings of the International Conference on Solid Waste Technology and Management; Widener University's School of Engineering: Philadelphia, PA, USA, 1999.

89. Shibuya, E.; Suguro, Y.; Akashi, T.; Nakao, T.; Hiraoka, H.; Nakahara, K. Vitrification for fly ash using electric-resistance furnace. NKK Tech. Rev. 2000, 82, 1-7.

90. Xiao, Y.; Oorsprong, M.; Yang, Y.; Voncken, J.H.L. Vitrification of bottom ash from a municipal solid waste incinerator. Waste Manag. 2008, 28, 1020-1026. 
91. Alorro, R.D.; Mitani S.; Hiroyoshi N.; Ito, M.; Tsunekawa, M. Recovery of heavy metals from MSW molten fly ash by carrier-in-pulp method: Fe powder as carrier. Miner. Eng. 2008, 21, 1094-1101.

92. Alorro, R.D.; Hiroyoshi N.; Ito, M.; Tsunekawa, M. Recovery of heavy metals from MSW molten fly ash by CIP method. Hydrometallurgy 2009, 97, 8-14.

93. Jiang, J.; Chen, M.; Zhang, Y.; Xu, X.; Luo, M. Sequestration of $\mathrm{CO}_{2}$ using municipal solid waste incinerator fly ash. J. Tsinghua Uni. 2008, 48, 2074-2078.

94. Ecke, H. Sequestration of metals in carbonated municipal solid waste incineration (MSWI) fly ash. Waste Manag. 2003, 23, 631-640.

95. Xu, X.; Jian, J.G.; Chen, M.Z.; Luo, M.; Zhang, Y.; Du, X.J. Investigation of the sequestration of $\mathrm{CO}_{2}$ and carbonation process for the stabilization of MSW fly ash. Environ. Sci. 2007, 28, 1644-1648.

96. Fernndez Bertos, M.; Li, X.; Simons, S.J.R.; Hills, C.D.; Carey, P.J. Investigation of accelerated carbonation for the stabilisation of MSW incinerator ashes and the sequestration of $\mathrm{CO}_{2}$. Green Chem. 2004, 6, 428-436.

97. Muchova, L.; Bakker, E.; Rem, P. Precious metals in municipal solid waste incineration bottom ash. Water Air Soil Pollut. 2009, 9, 107-116.

98. Astrup, T. Pretreatment and utilization of waste incineration bottom ashes: Danish experiences. Waste Manag. 2007, 27, 1452-1457.

99. Ferreira, C.; Ribeiro, A.; Ottosen, L. Possible applications for municipal solid waste fly ash. J. Hazard. Mater. 2003, 96, 201-216.

100. Pera, J.; Coutaz, L.; Ambroise, J.; Chababbet, M. Use of incinerator bottom ash in concrete. Cem. Concr. Res. 1997, 27, 1-5.

101. Juric, B.; Hanzic, L.; Ilic, R.; Samec, N. Utilization of municipal solid waste bottom ash and recycled aggregate in concrete. Waste Manag. 2006, 26, 1436-1442.

102. Ferraris, M.; Salvo, M.; Ventrella, A.; Buzzi, L.; Veglia, M. Use of vitrified MSWI bottom ashes for concrete production. Waste Manag. 2009, 29, 1041-1047.

103. Kikuchi, R. Recycling of municipal solid waste for cement production: Pilot-scale test for transforming incineration ash of solid waste into cement clinker. Resour. Conserv. Recycl. 2001, 31, 137-147.

104. Aubert, J.E.; Husson, B.; Vaquier, A. Use of municipal solid waste incineration fly ash in concrete. Cem. Concr. Res. 2004, 34, 957-963.

105. Ampadu, K.O.; Torii, K. Characterization of ecocement pastes and mortars produced from incinerated ashes. Cem. Concr. Res. 2001, 31, 431-436.

106. Park, Y.J.; Heo, J. Conversion to glass-ceramics from glasses made by MSW incinerator fly ash for recycling. Ceram. Int. 2002, 28, 689-694.

107. Shi, H.S.; Deng, K; Yuan, F.; Wu, K. Preparation of the saving-energy sulfoaluminate cement using MSWI fly ash. J. Hazard. Mater. 2009, 169, 551-555.

108. McCarthy, M.J.; Dhir, R.K. Development of high volume fly ash cements for use in concrete construction. Fuel 2005, 84, 1423-1432.

109. Rebeiz, K.S.; Mielich, K.L. Construction use of municipal-solid-waste ash. J. Energy Eng. 1995, 121, 2-12. 
110. Huang, W.J.; Chu, S.C. A study on the cementlike properties of municipal waste incineration ashes. Cem. Concr. Res. 2003, 33, 1795-1799.

111. Hui, C.W.; Porter, J.; McKay, G.; Cheung, R.; Leung, P. An integrated plant for municipal solid waste co-combustion in cement production. J. Solid. Waste. Technol. Manag. 2002, 28, 175-181.

112. Ampadu, K.O.; Torii, K. Chloride ingress and steel corrosion in cement mortars incorporating low-quality fly ashes. Cem. Concr. Res. 2002, 32, 893-901.

113. Choy, K.K.H.; Ko, D.C.K.; Cheung, W.H.; Fung, J.S.C.; Hui, D.C.W.; Porter, J.F.; McKay, G. Municipal solid waste utilization for integrated cement processing with waste minimization-A pilot scale proposal. Process Saf. Environ. Protect. 2004, 82, 200-207.

114. Murat, M.; Sorrentino, F. Effect of large additions of $\mathrm{Cd}, \mathrm{Pb}, \mathrm{Cr}, \mathrm{Zn}$, to cement raw meal on the composition and the properties of the clinker and the cement. Cem. Concr. Res. 1996, 26, 377-385.

115. Stephan, D.; Mallmann, R.; Knfel, D.; Hrdtl, R. High intakes of Cr, Ni, and Zn in clinker Part I. Influence on burning process and formation of phases. Cem. Concr. Res. 1999, 29, 1949-1957.

116. Kakali, G.; Parissakis, G. Investigation of the effect of $\mathrm{Zn}$ oxide on the formation of Portland cement clinker. Cem. Concr. Res. 1995, 25, 79-85.

117. Ubbriaco, P.; Calabrese, D. Hydration behavior of mixtures of cement and fly ash with high sulfate and chloride content. J. Therm. Anal. Calorim. 2000, 61, 615-623.

118. Rashid, R.A.; Frantz, G.C. MSW incinerator ash as aggregate in concrete and masonry. J. Mater. Civ. Eng. 1992, 4, 353-368.

119. Aubert, J.E.; Husson, B.; Sarramone, N. Utilization of municipal solid waste incineration (MSWI) fly ash in blended cement. Part 1: Processing and characterization of MSWI fly ash. J. Hazard. Mater. 2006, 136, 624-631.

120. Cinquepalmi, M.A.; Mangialardi, T.; Panei, L.; Paolini, A.E.; Piga, L. Reuse of cement-solidified municipal incinerator fly ash in cement mortars: Physico-mechanical and leaching characteristics. J. Hazard. Mater. 2008, 151, 585-593.

121. Mangialardi, T. Sintering of MSW fly ash for reuse as a concrete aggregate. J. Hazard. Mater. 2001, 87, 225-239.

122. Triano, J.R.; Frantz, G.C. Durability of MSW fly-ash concrete. J. Mater. Civ. Eng. 1992, 4, 369-384.

123. Robinson, R.; Thagesen, B. Road Engineering for Development; Spon: London, UK, 2004; p. 252

124. Ma, G.F.; Onitsuka, K.; Negami, T. Utilizations of incineration ash from municipal solid waste as admixtures for road embankment materials. Geotech. Eng. 2007, 38, 87-94.

125. Bruder-Hubscher, C.; Lagarde, F.; Leroy, M.J.F.; Couganowr, C.; Enguehard, F. Utilisation of bottom ash in road construction: Evaluation of the environmental impact. Waste Manag. Res. 2001, 19, 545-556.

126. Aberg, A.; Kumpiene, J.; Ecke, H. Evaluation and prediction of emissions from a road built with bottom ash from municipal solid waste incineration (MSWI). Sci. Total. Environ. 2006, 355, 1-12.

127. Francois, D.; Pierson, K. Environmental assessment of a road site built with MSWI residue. Sci. Total. Environ. 2009, 407, 5949-5960. 
128. Ore, S.; Todorovic, J.; Ecke, H.; Grennberg, K.; Lidelow, S.; Lagerkvist, A. Toxicity of leachate from bottom ash in a road construction. Waste Manag. 2007, 27, 1626-1637.

129. Nishida, K.; Nagayoshi, Y.; Ota, H.; Nagasawa, H. Melting and stone production using MSW incinerated ash. Waste Manag. 2001, 21, 443-449.

130. Andreola, F.; Barbieri L.; Corradi, A; Lancellotti, I.;. Manfredini, T. The possibility to recycle solid residues of the municipal waste incineration into a ceramic tile body. J. Mater. Sci. 2001, 36, 4869-4873.

131. Rawlings, R.D.; Wu, J.P.; Boccaccini, A.R. Glass-ceramics: Their production from wastes-A Review. J. Mater. Sci. 2006, 41, 733-761.

132. Kim, H.S.; Kim, J.M.; Oshikawa, T.; Ikeda, K. Production and Properties of Glass-Ceramic from Incinerator Fly Ash. In Materials Science Forum; Kim, H.S., Park, S.Y, Lee, S.W., Eds.; Elsevier: Gyungpodae, Korea, 2003; pp. 180-185.

133. Aloisi, M.; Karamanov, A.; Pelino, M. Sintered glass-Ceramic from municipal solid waste incinerator ashes. J. Non-Cryst. Solids 2004, 345-346, 192-196.

134. Park, Y.J.; Heo, J. Vitrification of fly ash from municipal solid waste incinerator. J. Hazard. Mater. 2002, 91, 83-93.

135. Park, Y.J.; Heo, J. Corrosion behavior of glass and glass-ceramics made of municipal solid waste incinerator fly ash. Waste Manag. 2004, 24, 825-830.

136. Glordano, P.M.; Behel, A.D., Jr; Lawrence, J.E., Jr; Soileau, J.M.; Bradford, B.N. Mobility in soil and plant availability of metals derived from incinerated municipal refuse. Environ. Sci. Techol. 1983, 17, 193-198.

137. Rosen, C.J.; Bierman, P.M.; Olson, D. Swiss chard and alfalfa responses to soils amended with municipal solid waste incinerator ash: Growth and elemental composition. J. Agric. Food Chem. 1994, 42, 1361-1368.

138. Lo, H.M.; Liu, M.H.; Pai, T.Y.; Liu, W.F.; Lin, C.Y.; Wang, S.C.; Banks, C.J.; Hung, C.H.; Chiang, C.F.; Lin, K.C.; Chen, P.H.; Chen, J.K.; Chiu, H.Y.; Su, M.H.; Kurniawan, T.A.; Wu, K.C.; Hsieh, C.Y.; Hsu, H.S. Biostabilization assessment of MSW co-disposed with MSWI fly ash in anaerobic bioreactors. J. Hazard. Mater. 2009, 162, 1233-1242.

139. Pollard, S.J.T.; Fowler, G.D.; Sollars, C.J.; Perry, R. Low-cost adsorbents for waste and wastewater treatment: A review. Sci. Total. Environ. 1992, 116, 31-52.

140. Babel, S.; Kurniawan, T.A. Low-cost adsorbents for heavy metals uptake from contaminated water: A review. J. Hazard. Mater. 2003, 97, 219-243.

141. Crini, G. Non-conventional low-cost adsorbents for dye removal: A review. Biores. Technol. 2006, 97, 1061-1085.

142. Shim, Y.S.; Kim, Y.K.; Kong, S.H.; Rhee, S.W.; Lee, W.K. The adsorption characteristics of heavy metals by various particle sizes of MSWI bottom ash. Waste Manag. 2003, 23, 851-857.

143. Ho, Y.S.; McKay, G. Comparative sorption kinetic studies of dye and aromatic compounds onto fly ash. J. Environ. Sci. Health Part A: Toxic/Hazard. Subst. Environ. Eng. 1999, 34, 1179-1204.

144. Ducom, G.; Radu-Tirnoveanu, D.; Pascual, C.; Benadda, B.; Germain, P. Biogas-Municipal solid waste incinerator bottom ash interactions: Sulfur compounds removal. J. Hazard. Mater. 2009, 166, 1102-1108. 
145. Khare, S.K.; Panday K.K.; Srivastava, R.M.; Singh, V.N. Removal of victoria blue from aqueous solution by fly ash. J. Chem. Tech. Biotech. 1987, 38, 99-104.

146. Panday, K.K.; Prasad, G.; Singh, V.N. Copper(II) removal from aqueous solutions by fly ash. Water Res. 1985, 19, 869-873.

147. Viraraghavan, T.; Rao, G.A.K. Adsorption of cadmium and chromium from wastewater by flyash. J. Environ. Sci. Health.-Part A 1991, 26, 721-753.

148. Sadowski, Z.; Polowczyk, I.; Bastrzyk, A.; Koźlecki, T.; Sawiński, W.; Rudnicki P.; Sokołowski, A.; Sadowski, Z. Use of fly ash agglomerates for removal of arsenic. Environ. Geochem. Health 2010, doi:10.1007/s10653-010-9306-x.

149. Fan, Y.; Zhang, F.S.; Feng, Y. An effective adsorbent developed from municipal solid waste and coal co-combustion ash for As(V) removal from aqueous solution. J. Hazard. Mater. 2008, 159, 313-318.

150. Ghaffar, A.; Tabata, M. Dechlorination/detoxification of aromatic chlorides using fly ash under mild conditions. Waste Manag. 2009, 29, 3004-3008.

151. Singh, B.K.; Rawat, N.S. Comparative sorption kinetic studies of phenolic compounds on fly ash and impregnated fly ash. J. Chem. Tech. Biotech. 1994, 61, 57-65.

152. Kesraoui-Ouki, S.; Cheeseman, C.R.; Perry, R. Natural zeolite utilisation in pollution control: A review of applications to metals' effluents. J. Chem. Techol. Biotechol. 1994, 59, 121-126.

153. Tao, Y.; Kanoh, H.; Abrams, L.; Kaneko, K. Mesopore-modified zeolites: Preparation, characterization, and applications. Chem. Rev. 2006, 106, 896-910.

154. Lin, C.F.; Hsi, H.C. Resource recovery of waste fly ash: Synthesis of zeolite-like materials. Environ. Sci. Technol. 1995, 29, 1109-1117.

155. Murayama, N.; Yamamoto, H.; Shibata, J. Mechanism of zeolite synthesis from coal fly ash by alkali hydrothermal reaction. Int. J. Miner. Process. 2002, 64, 1-17.

156. Yang, G.C.C.; Yang, T.Y. Synthesis of zeolites from municipal incinerator fly ash. J. Hazard. Mater. 1998, 62, 75-89.

157. Miyake, M.; Tamura, C.; Matsuda, M. Resource recovery of waste incineration fly ash: Synthesis of zeolites A and P. J. Am. Ceram. Soc. 2002, 85, 1873-1875.

158. Fan, Y.; Zhang, F.S.; Zhu, J.; Liu, Z. Effective utilization of waste ash from MSW and coal co-combustion power plant-Zeolite synthesis. J. Hazard. Mater. 2008, 153, 382-388.

159. Kwok, K.C.M.; Lee, V.K.C.; Gerente, C.; McKay, G. Novel model development for sorption of arsenate on chitosan. Chem. Eng. J. 2009, 151, 122-133.

160. Penilla, R.P.; Bustos, A.G.; Elizable, S.G. Zeolite synthesized by alkaline hydrothermal treatment of bottom ash from combustion of municipal solid wastes. J. Am. Ceram. Soc. 2003, 86, 1527-1533.

(C) 2010 by the authors; licensee MDPI, Basel, Switzerland. This article is an Open Access article distributed under the terms and conditions of the Creative Commons Attribution license (http://creativecommons.org/licenses/by/3.0/). 